\title{
Dom hajelmutirroi’.
}

e Bopfete Bhoeme-n ond Jü̈r

$$
\text { non }
$$

\section{Cáfar Slaifdlen.}

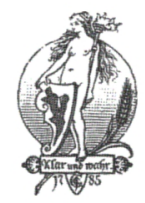

Stuttgart.

Б. I. Böjthen' ihe Derlagshandlung. 1892. 
Ģofbuḑ̧rữerei Breiner \& Pfeiffer, Stuttgart. 